\title{
Recalibration of Kainji Reservoir Operating Rule for Optimal Operation
}

\author{
Mohammed J Mamman* \\ Department of Agricultural Technology, College of Agriculture Mokwa, Nigeria
}

Submission: December 08, 2017; Published: January 08, 2018

"Corresponding author: Mohammed J Mamman, Department of Agricultural Technology, College of Agriculture Mokwa, Nigeria, Email: ikwan1565@gmail.com

\begin{abstract}
Reservoir rule curves guide reservoir operations by setting target reservoir elevations throughout the year. In multipurpose reservoirs, the rule curve represents the compromise between different objectives such as flood control and water supply. This research tends to recalibrate the operation rule curves of Kainji reservoir system so as to guide the managers in their operation and to moderate the extreme events of flood and water shortage for better operational efficiency. Standard linear operation policy (SLOP) was adopted in the recalibration of the reservoir system; it is chosen based on its simplicity, its operating policy is to provide as much of the target demand as possible, used for operational studies and planning, particularly for firm yield studies. The SLOP provides a simple method of making release decisions.The reservoir elements: initial storage, reservoir capacity, inflow, evaporation and demand were entered into the SLOP programme and the outputs: reservoir storage and release were obtained. From the results obtained, There was no significance difference in the monthly storages from April to July, but there was increase in the simulated storages between the months of August and February which depicts need to increase the reservoir storages. For reservoir level there was seemingly significant difference between the managers operated reservoir level and the proposed reservoir level from the months of July to October and marginal rise in the rest of the months for the release, there was sharp significant difference between the antecedent reservoir release rule curve and the SLOP release rule curve. From March to June of the proposed rule curve there was significant decrease of water to be released as compared to the managers operated release. The SLOP programme employed in this research shows need to increase the storages for more efficient reservoir operation.
\end{abstract}

Keywords : Reservoir; Standard Linear Operation Policy; Rule Curves Simulation and Calibration

\section{Introduction}

Reservoirs are those water bodies formed or modified by human activity for specific purposes, in order to provide a reliable and controllable resource [1]. They are managed in response to specific community needs; or provide water for developing human activities and demands. Fundamentally, a reservoir serves to store water and the size of the reservoir is governed by the volume of the water that must be stored, which in turn is affected by the variability of the inflow available for the reservoir [2]. The operation of reservoirs is a classical problem in water resources engineering with a long and distinguished history, spanning well over a century [3]. While much recent work on this problem has become very sophisticated, especially in dealing with multiplepurpose reservoirs the problem remains unresolved technically.

It is imperative to note that varying, hydro- meteorological dynamics leads to variation in key reservoir variables like the inflow, storage and outflow; because of this water managers face the challenge of making available adequate quantities of water for drinking, agricultural and others vis-a-vis the geometrically increasing population pressure and socioeconomic development, increase the needs and demands for particular water flows [4]. The role of water-storage reservoirs, therefore, is to impound water during periods of higher flows, thus preventing flood disasters, and then permit gradual release of water during periods of lower flows. The most important aspect of the reservoir planning is to estimate the quantity of water likely to be available in the river from year to year and seasons to season. For the determination of the required storage capacity of a reservoir, the runoff pattern of the river at the dam site is required.

Reservoirs are among the most effective systems for integrated water resources development and management. Currently, reservoirs have played an increasingly important role in balancing the contradiction between social development and water resources scarcity [5-7]. Several models and methods for reservoir operation have been proposed and reviewed [8-11]. 
Reservoir operation planning is an essential aspect of reservoir management in that by showing target storage levels in different months, the reservoir operation can be guided to ensure improved overall performance of the reservoir in terms of its reliability and vulnerability. Derivation of an operating policy often involves more complex analysis and requires specialist expertise [12].

Reservoir rule curves guide reservoir operations by setting target reservoir elevations throughout the year. In multipurpose reservoirs, the rule curve represents the compromise between different objectives such as flood control and water supply. A reservoir flood pool is traditionally sized based on the record of peak flows that occurred during the historical record. The record of annual peak flows is used to create a flood frequency curve and to estimate the flood magnitude that occurs with a specified frequency (e.g. once in 100 years, or the flood magnitude with a $1 \%$ chance of exceedance) [13]. A flood pool can then be designed to safely pass a certain size flood through the reservoir without downstream flooding, providing a target level of flood protection.

Reservoir operation consists of a series of decisions on whether to hold or release water. Decisions made in advance of the flood season include the flood pool size, which determines readiness, and during a flood, real-time time decisions are made about whether to store or release water. Water supply and flood control are, to some extent, conflicting goals. For water supply, operations should keep the reservoir as full as possible and for flood control; operations should keep the reservoir empty to be available to capture flood peaks floods [13]. A rule curve can be established to optimise tradeoffs and balance risks in operational decisions.Reservoir rule curves, which are a basic guidance for reservoir operating policy, however, are not as complex to derive and use but, unlike operating policies, they do not prescribe the amount of water to be released [12].

Changes in rainfall, temperature and evapotranspiration affect water resources availability and demands, and hence the performance of reservoir- based systems: in order to accommodate these changes in the water resources situation, there must be substantial improvement in reservoir operating policy and water use and management efficiency, but this can only be meaningfully done if the impact of climate change and variability is quantified [14].

Reservoir operators need to know how much water to release and when. Reservoirs designed to meet demands for water supplies, recreation, hydropower, the environment and/or flood control need to be operated in ways that meet those demands in the most reliable and effective manner. Since future inflows or storage volumes are uncertain, the challenge, of course, is to determine the best reservoir release or discharge for a variety of possible inflows and storage conditions. Reservoir release policies are often defined in the form of what are called 'rule curves [15]. Release rules may also specify the desired storage level for the time of year [15]. The operator is to release water as necessary to achieve these target storage levels.

Maximum and minimum release constraints might also be specified that may affect how quickly the target storage levels can be met. Some rule curves define multiple target storage levels depending on hydrological conditions in the upstream watershed, or on the forecast climate conditions, solar geomagnetic activity, ocean currents and the like. Reservoir release rule curves for a year define a policy that does not vary from one year to the next. The actual releases will vary, however, depending on the inflows and storage volumes that actually occur. The releases are often specified independently of future inflow forecasts.

They are typically based only on existing storage volumes and within-year periods. Release rules are typically derived from trial and error simulations. To begin these simulations, it is useful to have at least an approximate idea of the expected impact of different alternative policies on various system performance measures or objectives [15]. Policy objectives could be the maximization of expected annual net benefits from downstream releases, reservoir storage volumes, hydroelectric energy and flood control, or the minimization of deviations from particular release, storage volume, hydroelectric energy or flood flow targets or target ranges.

Multiple reservoirs need to be operated and regulated efficiently with a high degree of intelligence, intuition, and experience, in other to ensure that they are neither left partially empty by the end of the rainy season, nor they are found full at the time of arrival of a series of peak floods, leading to heavy releases, causing floods in the downstream valley [16]. Reservoir regulating committees, consisting of experts are therefore generally constituted to ensure issue of proper and timely directives to the staff operating the gated openings of the reservoir, to avoid any bad and inefficient operations.

Guiding tables and curves called curve rule or guide curves are drawn in advance, and kept ready for use for the efficient regulation of the reservoir water, with time. Such guiding curves are normally required only for the flood season, because for the rest of the year, the reservoir will only discharge water for irrigation and hydroelectric needs [16]. Sometimes, reservoir regulation manuals are also prepared and made available to the officers, dealing with the operation of the gates of the reservoir. Such manuals provide guidelines for gate operations, and for the overall maintenance and upkeep of the dam and reservoir. A rule curve, either in tabular or graphical form, as framed by the experts on the basis of the past data, broadly reflects the maximum reservoir levels to be achieved by the different dates of the rainy season. Such curves, therefore reflects the vacant space to be left in the reservoir on different dates or weeks of the rainy season. Such curves may have to be revised from time to time, based on their performance during their actual use [16]. 
All reservoir system simulation models require the specification of reservoir operating rules. These rules determine the release and storage decisions for each reservoir at each time-step during the simulation. A reservoir operating policy is a sequence of release decisions in operational periods [such as months], specified as a function of the state of the system. The state of the system in a period is generally defined by the reservoir storage at the beginning of a period and the inflow to the reservoir during the period. Once the operating policy is known, the reservoir operation can be simulated in time with a given inflow sequence. A number of optimization algorithms have been developed for deriving reservoir operating policies. However, the most common policy implemented in practice is the so-called standard linear operating policy. This policy by itself is not based on or derived from any optimization algorithm. The standard operating policy [SLOP] aims to best meet the demand in each period based on the water availability in that period. It thus uses no foresight on what is likely to be the scenario during the future periods in a year.

For a single reservoir providing water supply downstream, the most straight forward operating policy is to provide as much of the target demand as possible. If insufficient water is available to meet target demands, the reservoir is emptied to make releases as close to the target as possible. Water available in excess of the target release is stored. Water exceeding both the release target and available storage capacity is spilled downstream [17]. The SLOP provides a simple method of making release decisions, although in actual operation, strict implementation of this rule is rare due to a desire to maintain at least some water to avoid extremely severe shortages. When the amount of available water is less than the target demand, rarely would operators completely empty a reservoir. Most reservoir systems employ some sort of water conservation to reduce demands before a reservoir would run dry.

\section{Materials and Method}

The hydrological data employed for this study were stream flow, rainfall, reservoir level, and evaporation records.

\section{The Study Area}

Geographically, Kainji hydroelectric dam is located in New Bussa town now headquarter of Borgu local government area of Niger State, Nigeria. The lake created behind the dam span between latitude $9^{\circ} 8^{\prime}$ to $10^{\circ} 7^{\prime}$ and between longitude $4^{\circ} 5^{\prime}$ to $4^{\circ} 7^{\prime} \mathrm{E}$ with reference point $9.54 \mathrm{~N}$ and $4.38 \mathrm{E}$ northwest of the Federal Capital Territory [FCT, Abuja] [18].

\section{Hydrology of the Niger River system}

The average rainfall at the headwaters of Niandan and Milo rivers at the source of the Niger at the Fouta Djallon Mountains in Guinea and its exit to the sea in Nigeria is $2200 \mathrm{~mm}$. The river flow regime is characterized by two distinct flood periods occurring annually namely the White and Black floods. The black flood derives its flow from the tributaries of the Niger outside Nigeria [flow lag October to May] and arrives at Kainji reservoir [Nigeria] in November and lasts until March at Jebba after attaining a peak rate of about 2,000m3/sec in February [19]. The White flood is a consequent of flows from local tributaries especially the SokotoRima and Malendo river systems. The White flood is heavily laden with silts and other suspended particles [flow lag June to September] and arrives Kainji in August in the pre-Kainji Dam River Niger having attained a peak rate of 4,000 to $6,000 \mathrm{~m} 3 / \mathrm{sec}$ in September-October in Jebba. The critical low flow period into the Kainji reservoir is March and July each year.

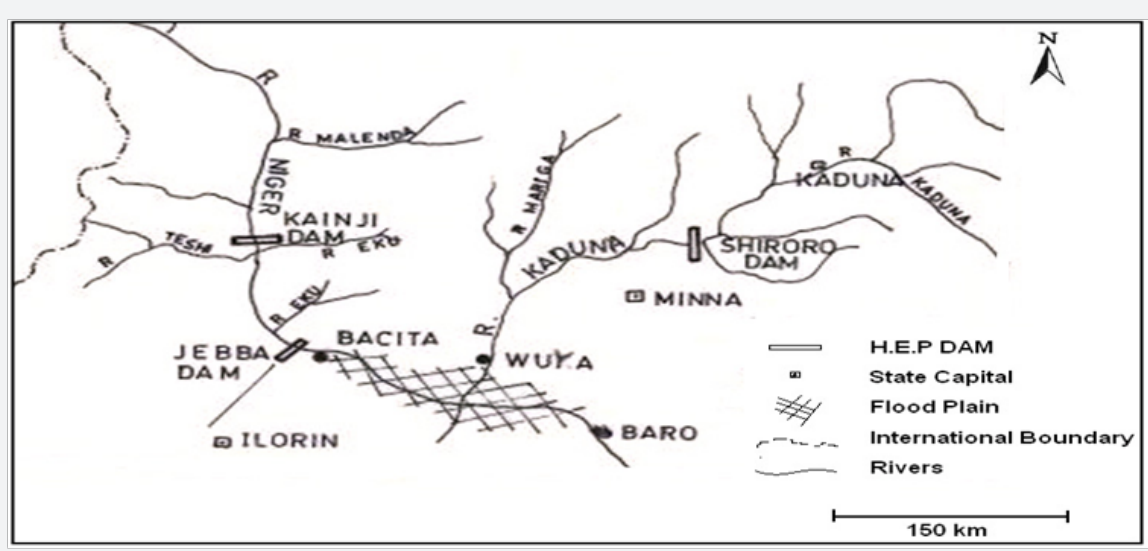

Figure 1: Location of Kainji Hydroelectric Dam.

\section{Data Base}

(Figure 1,2) The data base for this study constitutes of varying temporal hydro-meteorological time sequence. It is made of daily inflow and reservoir draw- down data for the period of twenty five [1990-2014] and twenty [1995-2014] years, respectively, monthly average rainfall spanning fifty years [1965-2014], fourty five years [1969 -2013] monthly outflow and lake evaporation for 41 years [1974-2014] were also obtained from the Hydrology department of Kainji dam, Niger state. 


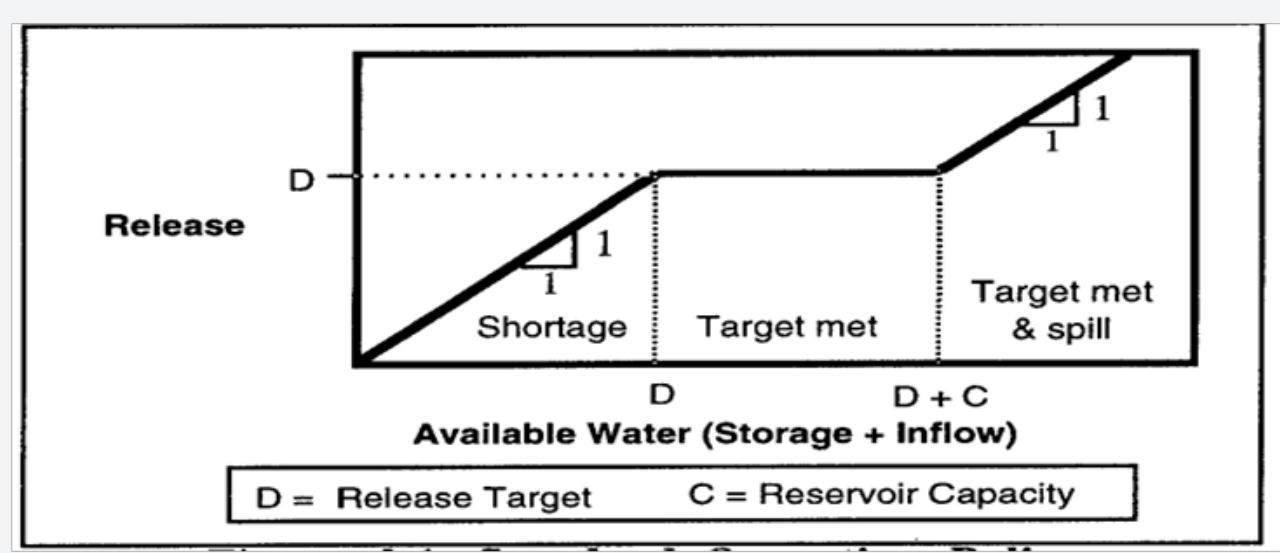

Figure 2: Standard Linear Operating Policy, Source: (UAEHEC), (1996).

\section{Re-Calibration of Reservoir Operating Policy}

Standard linear operation policy [SLOP] was adopted in the recalibration of the reservoir system; it is chosen based on its simplicity, its operating policy is to provide as much of the target demand as possible, used for operational studies and planning, particularly for firm yield studies. The SLOP provides a simple method of making release decisions. The policy is that if insufficient water is available to meet target demands, the reservoir is emptied to make releases as close to the target as possible. Water available in excess of the target release is stored. Water exceeding both the release target and available storage capacity is spilled downstream [20]. The release curve for this standard linear operating policy [SLOP] is as shown in [Figure 3]

The SLOP scheme as implemented in this study was defined as:

$$
\begin{aligned}
& \text { If }\left[S_{t}+I_{t}\right]<D_{t} \text { then } R_{t}=\left[S_{t}+I_{t}\right] \\
& \text { elseif }\left[\left(S_{t}+I_{t}\right)<\left(C+D_{t}\right)\right] \text { then }_{t}=D_{t} \\
& \text { elseR }_{t}=S_{t}+I_{t}-c
\end{aligned}
$$

End if

where St $=$ storage at beginning of period $t$,

$I_{t}=$ inflow in period $t$,

$\mathrm{D}_{\mathrm{t}}=$ water demand in period $\mathrm{t}$,

$\mathrm{R}_{\mathrm{t}}=$ release in period $\mathrm{t}$, and

$\mathrm{C}=$ reservoir Capacity.

The reservoir elements: initial storage, reservoir capacity, inflow, evaporation and demand were entered into the SLOP programme and the outputs: reservoir storage and release were obtained.

\section{Results and Discussion}

\section{Calibration of Reservoir operating Policy}

The reservoir system was recalibrated using standard linear operating policy and the results of the recalibrated rule curves for the storage, reservoir level and release are as presented below;

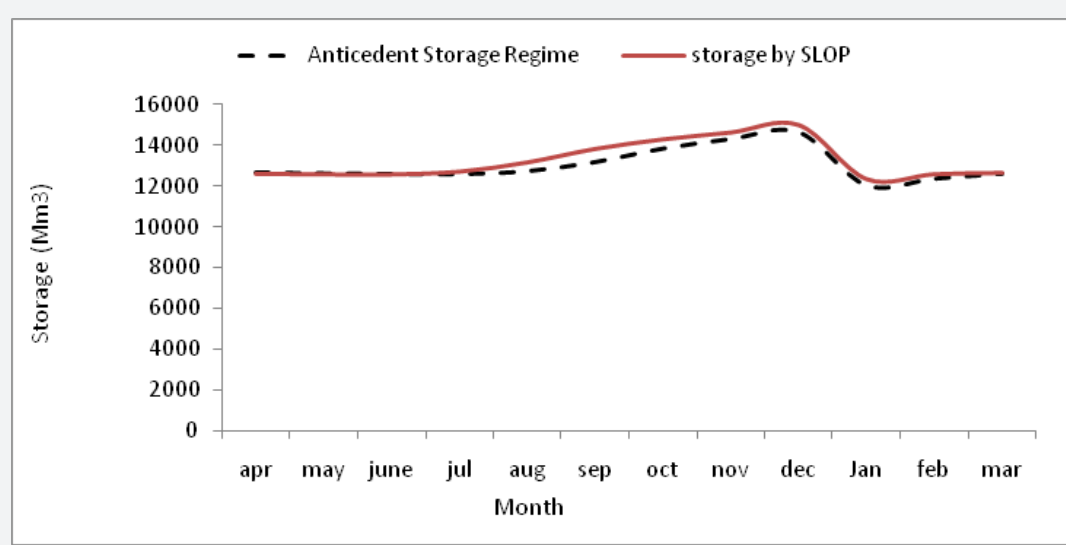

Figure 3: Kainji reservoir storage rule curve.

Kainji reservoir storage rule curve as operated by managers and as simulated by standard linear operation policy is shown in Figure 3. From the figure it's obvious that no significance difference in the monthly storages from April to July, but there is 
increase in the simulated storages between the months of August and February which depicts need to increase the reservoir storages. This is imperative owing to the fact that months of August to February are usually high flood period as depicted in the inflow series, increasing the storages will accommodate more flow and this can curtail flooding at the downstream as experienced usually annually along the downstream sector. This could also be healthy for the dam to have enough storage as the preceding months of March to June when incipient rainfall and low flows are experienced. It is worth nothing that one of the problems associated with the operation policy of the current reservoir system is the annual flooding of lower Niger plains when the spillways are opened in September during high inflows. While during the period of low inflows [March to June], head of water in the reservoir is often below the desired level for maximum power generation.

Figure 4 indicates the reservoir level rule curve for Kainji as operated by managers and as recalibrated employing SLOP. There is seemingly significant difference between the managers operated reservoir level and the proposed reservoir level from the months of July to October and marginal rise in the rest of the months this is imperative owing to the fact that months of incipient rain and low flow of April to July call for more storage which consequently increases the reservoir level. In the months of August to November when the flow is significantly higher there is consequent rise in the reservoir level. Accommodating more flows i.e., more storage during high floods can significantly reduce flooding and prepare more storage for the low flow periods of March to June. The dam reservoir operating policy call for recalibration owing to annual flooding experienced in the downstream sector in the months of August to November and low shortages in the months of March to June. Managers often employ experience in the operation of the reservoir which may not be adequate a times; based on experience of the water managers. If a wet year is preceded by a dry year, the managers adopt the operation policy of the dry year for the wet year, which is inadequate and the effect is flooding of the downstream. Generally, the emptying of the reservoir starts at least in February, towards the end of the dry season, and continues up to July and August when reservoir gets down to its lowest level. The reservoir then reaches its minimal level of exploitation. The white flood then makes it possible to commence the filling raising the level of the reservoir. When the rainy season is over, around end of October-November, it is the arrival of the Malian flood [Black Flood] which makes it possible to complete the filling which ends in January this is obvious to from (Figure 4).

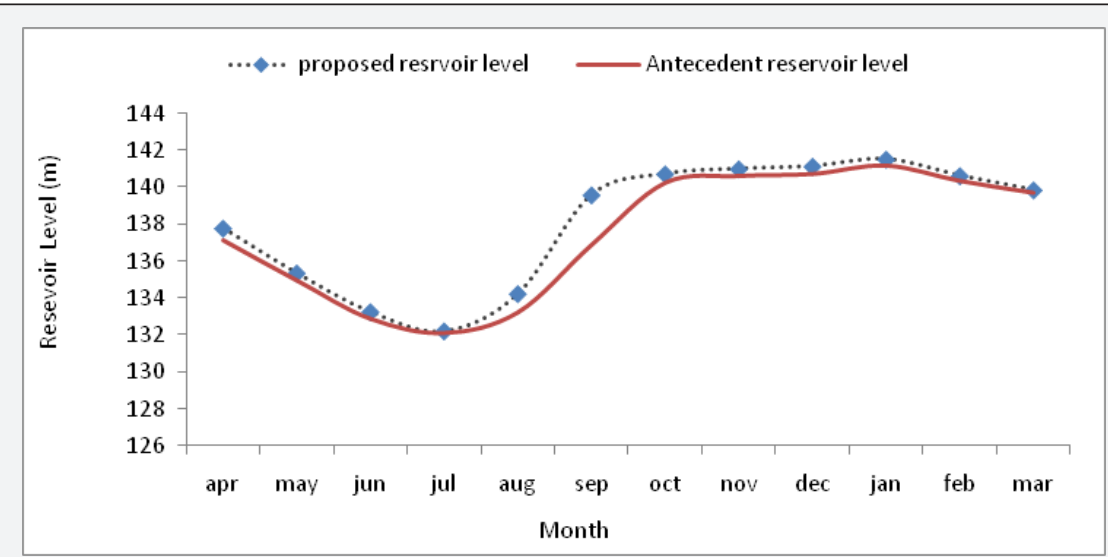

Figure 4: Reservoir level rule curve for Kainji Dam.

Viewing the antecedent release rule curve for Kainji dam and the SLOP proposed release (Figure 5). There is sharp significant difference between the antecedent reservoir release rule curve and the SLOP release rule curve. From March to June of the proposed rule curve there is significant decrease of water to be released as compared to the managers operated release. March to June are periods of incipient rainfall considering the hydrological period of the study area, low inflow is expected. Increase in the release beyond the proposed release will lead to excessively low level of water in the reservoir which brings about in efficiency of the reservoir especially in power generation. Reduction in the release consequently lead to more storage and rise in the reservoir level as shown in Figures $3 \& 4$, this is imperative owing to the need For more storage during incipient rain and low Flow of the period For efficient turbine operation For power supply. The month of September [high inflow] actually require more release even as more Flow is been stored, as compared to the operated release, this is paramount considering the safety of the dam. IF more Floods is not released and at the same time stored, the dam capacity at a period may be exceeded leading to collapse, this will be disastrous to the downstream users. Since this period is a peak period of flow in the season, the proposed release will mitigate the incidence of frequent annual Flooding. The difference in the release periods are indicated in the reservoir working (Table 1). 
Table 1: Reservoir Working Table for Kainji Dam.

\begin{tabular}{|c|c|c|c|c|c|c|c|}
\hline Month & Inflow (m3/sec) & $\begin{array}{c}\text { Antecedent } \\
\text { Reservoir } \\
\text { Storage (Mm3) }\end{array}$ & $\begin{array}{c}\text { Proposed } \\
\text { Reservoir } \\
\text { Storage (Mm3) }\end{array}$ & $\begin{array}{c}\text { Antecedent } \\
\text { Reservoir } \\
\text { Level(m) }\end{array}$ & $\begin{array}{c}\text { Proposed } \\
\text { Reservoir } \\
\text { Level (m) }\end{array}$ & $\begin{array}{c}\text { Antecedent } \\
\text { Reservoir } \\
\text { Release (Mm3) }\end{array}$ & $\begin{array}{c}\text { Proposed } \\
\text { Reservoir } \\
\text { Release (Mm3) }\end{array}$ \\
\hline Apr & 131.95 & 12634.34 & 12687.79 & 137.13 & 137.77 & 1036.625 & 98.96 \\
\hline May & 81.46 & 12587.79 & 12660.91 & 134.94 & 135.34 & 925.5417 & 61.09 \\
\hline Jun & 122.26 & 12560.91 & 12666.17 & 132.85 & 133.24 & 786.3333 & 91.7 \\
\hline Jul & 655.99 & 12556.17 & 12696.20 & 132.07 & 132.52 & 626.375 & 491.99 \\
\hline Aug & 1862.46 & 12696.2 & 13141.93 & 133.21 & 134.22 & 766.25 & 1396.84 \\
\hline Sep & 2743.94 & 13141.93 & 13803.16 & 136.88 & 139.58 & 1246.917 & 2057.96 \\
\hline Oct & 2030.27 & 13803.16 & 14271.61 & 140.26 & 140.712 & 1443.167 & 1522.7 \\
\hline Nov & 1548.73 & 14271.61 & 14602.58 & 140.64 & 140.99 & 1112.417 & 1161.55 \\
\hline Dec & 1708.73 & 14602.58 & 14970.67 & 140.75 & 141.13 & 1138.583 & 1281.55 \\
\hline Jan & 1617.77 & 12000.00 & 12331.41 & 141.21 & 141.5127 & 1186.5 & 1213.33 \\
\hline Feb & 1334.49 & 12331.41 & 12570.94 & 140.37 & 140.619 & 1177.042 & 1000.87 \\
\hline Mar & 642.57 & 12570.94 & 12634.34 & 139.71 & 139.85 & 1064.542 & 481.93 \\
\hline
\end{tabular}

\section{Conclusion}

The above results indicates the inadequacy of the Kainji operating rule curves and therefore recalibrated using standard linear operation policy [SLOP] programme. The rule curves for storage, release and reservoir levels developed indicates need for increase in storages. The results of the SLOP depict better performance of the reservoir system operation especially during extreme events of flood and drought. It also shows that mores water can be stored for a more efficient energy generation.

\section{Recommendations}

To further build on this study, the Followings are recommended:

a. It is recommended that the managers of the reservoir should adopt the recalibrated operation policy [SLOP] this could maximize the benefit of impounding the water of River Niger and also minimize the annual Flooding of the river plain.

b. Other reservoir calibration measures like the Hedging Rules can investigated

\section{References}

1. Thornton J, Steel A, Rast W (1996) Water Quality Assessments -A Guide to Use of Biota, Sediments and Water in Environmental Monitoring Second Edition. University Press, Cambridge, USA, PP. 1-609.

2. World Water Assessment Programme (2003) The United Nations Water Development Report. Water for People, Water for Life.

3. US Army Corps of Engineers Hydrologic Engineering Center (UAEHEC) (1996) Developing Seasonal and Long-term Reservoir System Operation Plans using HEC-PRM. Department of the Army Corps of Engineers, Water Resources Support Center Hydrologic Engineering Center 609 Second Street Davis, California, pp. 95615-4686.

4. Falkenmark M, Mikulski Z (2004) The Key Role of Water in the Landscape System: Conceptualisation to Address Growing Human Landscape Pressure, Geojournal 33(4): 355-363.
5. Guo SL, Zhang HG, Chen H (2004) A reservoir flood forecasting and control system in China. Hydrological Sciences Journal 49(6): 959-972.

6. Li QF, Yu MX, Zhao JH (2013) Impact of the Three Gorges Reservoir operation on downstream ecological water requirements. Hydrology Research 43(1-2): 48-53.

7. Urbaniak M, Kiedrzyńska E, Zalewski M (2013) The role of a lowland reservoir in the transport of micro pollutants, nutrients and the suspended particulate matter along the river continuum. Hydrology Research 43(4): 400-411.

8. Yakowitz S (1982) Dynamic programming application in water resources. Water Resources Research 18(4): 673-696.

9. Yeh W (1985) Reservoir management and operations models: A stateof-the-art review. Water Resources Research 21(12): 1797-1818.

10. Simonovic S (1992) Reservoir system analysis: Closing gap between theory and practice. Journal of Water Resources Planning and Management 118(4): 262-280.

11. Wurbs RA (1993) Reservoir-system simulation and optimization models. Journal of Water Resources Planning and Management 119(4): 455-472.

12. Adeloye A, Lallemand F, Mcmahon T (2003) Regression Models for Within-Year Capacity Adjustment in Reservoir Planning. Hydrological Science Journal 48(4): 53-52.

13. US Army Corps of Engineers (2002) Forecast-based Advance Release at Folsom Dam: Effectiveness and Risk -Phase1 (PR-48). pp. 1-111.

14. Sharad K, Jain D (2010) Investigating the behavior of statistical indices for performance assessment of a reservoir. Journal of Hydrology. Indian Institute of Technology, Roorkee 247667, India, 391: 90-96.

15. Loucks DP, Eelco VB (2005) Water Resources Systems Planning and Management. An Introduction to Methods, Models and Applications. United Nations Educational, Scientific and Cultural Organization 7, place de Fontenoy F-75352 Paris 07 Spain, pp. 231-332.

16. Kumar T (2013) Operations research in water quality management. Harvard Water Resources Group, Cambridge, UK.

17. Shilh M, Re Velle H (1994) Understanding performance measures of reservoirs. J Hydrol 324: 359-382.

18. Dukiya JJ (2013) Spatial Analysis of the Impacts of Kainji Hydropower Dam on the Down Stream Communities an Overview. A Journal of Geoinformatics and Geostatist: An overview 4(4): 105-113. 
19. Oyebande L, VO Sagua, JL Ekpenyong (1980) The effect of Kainji Dam on the hydrological regime, water balance and water quality of the River Niger The influence of man on the hydrological regime with special reference to representative and experimental basins: IAHSAISH Publ 130: 221-228.
20. Urbaniak M, Kiedrzyńska E, Zalewski M (2013) The role of a lowland reservoir in the transport of micro pollutants, nutrients and the suspended particulate matter along the river continuum. Hydrology Research 43(4): 400-411.

Your next submission with Juniper Publishers
will reach you the below assets
- Quality Editorial service
- Swift Peer Review
- Reprints availability
- E-prints Service
- Manuscript Podcast for convenient understanding
- Global attainment for your research
- Manuscript accessibility in different formats
( Pdf, E-pub, Full Text, Audio)
- Unceasing customer service
Track the below URL for one-step submission
https://juniperpublishers.com/online-submission.php

